\title{
Bölcsődéztetési tervek Magyarországon
}

\author{
Kapitány Balázs \\ KSH-Népességtudományi Kutatintézet
}

\begin{abstract}
Absztrakt
A kisgyermekkori ellátás intézményesített formái (ez Magyarországon elsősorban a bölcsőde különféle formáit jelenti), az ezzel kapcsolatos döntések és dilemmák szakterületek és tudományterületek metszéspontjában helyezkednek el. Tanulmányunkban a Kohorsz 18 Magyar Születési Kohorszvizsgálat adatait elemezve mutatjuk be a magyarországi kismamák bölcsődéztetési igényeit és terveit - általánosságban, illetve különféle jellemzők szerint. Azt vizsgáljuk, mennyire meghatározó, hogy demográfiailag, szociálisan, társadalmilag kik, milyen családok tervezik/szeretnék bölcsibe íratni a gyermekeiket, valamint hogy ennek milyen következményei lehetnek a társadalmi egyenlőtlenségek újratermelődésére. Kitérünk arra, hogy a jelenlegi szülői igények mekkora tényleges férőhely-kapacitást jelentenének, illetve arra is, hogy ezen igényelt kapacitásnak a mértéke hogyan befolyásolható a bölcsőde-óvoda átmenet rugalmasságának szabályozásával.
\end{abstract}

Kulcsszavak: bölcsőde, szülői igények, Magyar Születési Kohorszvizsgálat

\section{A kora gyermekkori intézményi ellátás társadalmi funkciói}

A kora gyermekkori intézményekben történő ellátás (az úgynevezett intézményes nevelés), és így a bölcsődei ellátás közösségi haszna, kiemelt állami támogatása mellett több különböző érvet szoktak felhozni. Anélkül, hogy részletesen áttekintenénk a kapcsolódó bőséges szakirodalmat, az alábbiakat érdemes röviden felvillantani.

A munkaerőpiaci központú érvelés szerint a gyermekek korai intézményes nevelése lehetővé teszi az anya munkába állását, visszatérését a szülés előtti munkahelyére. Ez értelemszerüen azonnali hatállyal hozzájárul a kisgyermekes nők és családjaik munkapiaci és így anyagi helyzetének javításához, hiszen a család munkajövedelme az anya jövedelmével megnő, és ez a növekmény a legtöbb esetben lényegesen magasabb, mint a bölcsőde közvetlen és közvetett költségei. A korai munkába visszatérésnek jellemzően hosszú távon is pozitív a hatása a nő keresete, szakmai karrierje szempontjából (Brilli et al., 2013; Szabó-Morvai \& Lovász, 2017).

A bölcsődei ellátásnak hatása lehet a gyermek további fejlődésére is. Sok vizsgálat jutott arra az eredményre, hogy általánosságban a már a kora gyer- 
mekkori ellátórendszerben résztvevő gyermekek jobban fejlődnek, a későbbiekben jobban teljesítenek, mint az otthon anya vagy rokon által nevelt gyermekek. Természetesen a gyermek intézményes nevelése esetén felmerülhetnek esetleges negatív következmények is: például sérül az anya-gyermek kötődés, szocializációs zavarok léphetnek fel. A szakirodalom azonban e téren sokkal megosztottabb, nem egyértelmű az sem, hogy van-e egyáltalán életkori határ, amíg általában/jellemzően jobb egy 'átlagos' kisgyermeknek otthon maradni az édesanyjával, és ha igen, hol húzható meg ez a határ. Ha van is ilyen határ, annyi biztosan állítható, hogy a magyar közvélemény többségének vélekedésével szemben (miszerint a kisgyermekeknek hároméves korig otthon, anyjuk mellett van a helyük), ez valahol a gyermek egy éves kora környékén vagy ez előtt lehet (általános összefoglaló magyar nyelven: Blaskó, 2013; olasz eredmények: Brilli, 2013). Mivel - mint majd látni fogjuk - Magyarországon jelenleg igen ritka az egy éves korban vagy korábban bölcsibe kerülő gyermek, így a magyarországi viszonyok között a bölcsődei kapacitások növelésétől alapvetően pozitív gyermekfejlődési hatásokat várhatunk.

A korai intézményi ellátás melletti harmadik érv elsődlegesen szociális és esélykiegyenlítő jellegű, a koragyermekkori intézményes gyermeknevelés hátrányos helyzetü családból származó gyermekekre vonatkozó pozitív hatását hangsúlyozza. E szerint a bölcsődei nevelés-gondozás - ideális esetben - segíti a hátrányos helyzetü családba született gyermekeket a hozott társadalmi hátrányok leküzdésében, a későbbiekben a társadalomba való jobb beilleszkedésben, javítja későbbi eredményeiket (Melhuish et al., 2008; Havnes-Mogstad, 2011; Hódi \& Tóth, 2016). Így tehát egy jól müködő intézményi ellátórendszer képes lehet kompenzálni a családból hozott társadalmi hátrányokat, és így hozzájárul a társadalmi egyenlőtlenségek csökkentéséhez. Ez az intézményrendszer természetesen lehet általános (mint Magyarországon a bölcsőde), vagy társadalmilag célzott (mint a Biztos Kezdet Gyermekházak). Itt továbbá érv szokott lenni, hogy a kora (minél korábbi) gyermekkorban történő beavatkozás sokkal (költség)hatékonyabb, s az ekkori állami befektetések sokkal jobban megtérülnek. Amikor 2015-ben Magyarországon az óvodakötelezettség életkorát ötről három évre leszállították, akkor e mögött is alapvetően ez a szociális, esélykiegyenlítő érvrendszer húzódott meg, még ha ezt egyesek, vitatják is (például Lukács, 2017).

A következő érv demográfiai jellegü. Több komoly kutatás jutott arra az eredményre, hogy egy magas színvonalú, nagy lefedettségű bölcsődei hálózat pozitívan hat a gyermekvállalási tervekre és a tényleges termékenységre is (például Del Boca, 2002; Hank-Kreyenfeld, 2003; Bauernschuster et al., 2016). Noha a hatás oksági mechanizmusa nem teljesen egyértelmü, feltehetően arról van szó, hogy a családok szívesebben vállalnak - jellemzően újabb - gyermeket, ha tudják, hogy amennyiben a szülést követően munkát kell vagy szeretnének vállalni, a gyermek színvonalas intézményi ellátása megoldható. A jól fejlett, kiterjedt, elérhető bölcsődei hálózat léte tehát olyan biztonsági hálót jelent, amely hatására a családok könnyebben döntenek a 
gyermekvállalás mellett, még abban az esetben is, ha eredendően nem is tervezik a tervezgetett gyermek bölcsődébe adását.

A koragyermekkori ellátás szerepe kapcsán Magyarországon a jogalkotó is párhuzamosan érvel a fenti társadalmi funkciókkal. A bölcsődefejlesztési program a népesedéspolitikai, demográfiai célt - a gyermekvállalási kedv növelését - célzó „családvédelmi akcióterv” részeként került meghirdetésre. A bölcsődefejlesztési programot elrendelő 1691/2017. (IX. 22.) Korm. határozat ugyanakkor a „kisgyermekes anyák munkába állásának elősegítésére” hivatkozva rendeli el a bölcsődefejlesztési program kiterjesztését. A szociális felzárkóztatás alapját jelentő Magyar Nemzeti Társadalmi Felzárkózási Stratégia a társadalmi felzárkózás lehetséges eszközeként tekint a bölcsődére. Ez az összetett hozzáállás jól látszik a bölcsődei felvétel rendjének törvényi szabályozásában, amely egyszerre preferálja a dolgozó szülők gyermekeit, a (legritkábban a dolgozó szülők által nevelt) rendszeres gyermekvédelmi kedvezményre jogosult gyermeket, és olyan demográfiai célcsoportokat, mint a nagycsaládosok és az egyedülálló szülők gyermekei (lásd gyermekvédelmi törvény 43. \$).

\section{A szülői döntések szerepe az intézményválasztásban}

Tehát noha sok érv szól egy kiterjedt kora gyermekkori intézményrendszer működtetése mellett, az empirikus vizsgálatok sok esetben nem támasztják alá a várt pozitív hatásokat, sőt akár negatív hatásokat is feltárnak. Ebben nagy szerepet tulajdonítanak az intézményi hozzáférés korlátainak, illetve a szülői igényeknek.

A hazai szakirodalomban Keller (2018) tanulmánya plasztikusan mutatja be a bölcsődék kapcsán az intézményi hozzáférés korlátait. Keller a bölcsődei felvétel rossz, nem egyértelmủ szabályozási hátterét teszi azért felelőssé, hogy a rossz helyzetben lévő családok nem, vagy csak nehezen tudják érvényesíteni a bölcsődei ellátásra való jogosultságukat. Míg tehát az intézményi hozzáférés magyarországi korlátai ismertek és valamennyire kutatottak is, addig - ismereteim szerint - eddig senki nem foglalkozott az aszimmetrikus szülői igények kérdésével. Vagyis azzal a kérdéssel, hogy a különféle helyzetű családok egyáltalán milyen arányban igénylik gyermekeik bölcsődei ellátását, s mennyiben tartják egyáltalán a gyermek számára jónak a bölcsődéztetést.

Amennyiben a rosszabb társadalmi helyzetü, alacsonyabb kulturális tőkével rendelkezők valamilyen okból kevésbé tartják szükségesnek/fontosnak a formális kisgyermekkori ellátórendszer igénybevételét és inkább az informális gyermeknevelési csatornákra támaszkodnak (például nagyszülö) abban az esetben ez a rendszer - akár az állami törekvésekkel szemben - éppen a társadalmi egyenlötlenségek újraörökítésének az eszköze lehet, teljesen függetlenül az intézményi ellátás korlátaitól.

Márpedig ez a jelenség ismert a nemzetközi szakirodalomban is (többek között Capizzano \& Adams, 2010; Campbell et al., 2010; Simon et al., 2017). Ráadásul sok esetben összetett nehézséget jelentenek a kisebbségi szülők 
formális korgyermekkori ellátórendszerrel kapcsolatos fenntartásai. Az, hogy a rosszabb szociális helyzetü, kisebbségi szülők távol maradnak/távol tartódnak a formális kisgyermekkori intézményrendszertől, nem csak esélyegyenlőségi hanem gyermekfejlődési és munkapiaci szempontból is káros lehet (Liang et al., 2000; Webb-Donna, 2014; Huston et al., 2002).

Magyarországról lényegesen kevesebb adat áll rendelkezésre. Ugyanakkor Makay Zsuzsa (2018) országos kérdőíves kutatásokon nyugvó eredményei arra utalnak, hogy hazánkban is mindmáig jelentősek a fenntartások a közvéleményben a bölcsődékkel szemben. 2016-os adatok szerint még a válaszadók csaknem fele (45\%-a) azt az állítást sem tudja elfogadni, miszerint: „Ha elég bölcsőde lenne az országban, teljesen elfogadható lenne, hogy az anyák a gyermek kétéves kora után visszamenjenek dolgozni." A gyermekvállalási korban lévő nők mintegy fele nem ért egyet azzal az állítással sem, miszerint „A bölcsődébe járó kisgyerekek nem kapnak rosszabb gondoskodást, mint azok, akikkel otthon marad az anyjuk".

A 2011/2012. évi bölcsődevizsgálat eredményei (Nyitrai, 2015) - amely csak a közép-magyarországi régió bölcsődéire terjedt ki -, a szülők magas átlagos végzettségét mutatták: a bölcsődés gyermekek szüleinek mintájában az anyák 56\%-a, az apák 44\%-a rendelkezett felsőfokú végzettséggel. Ez mindenképpen arra utal, hogy önkéntesen vagy szelekció útján, de Magyarországon különböző az egyes társadalmi, iskolai végzettségi csoportok bölcsődéztetési gyakorlata.

\section{A hazai intézményi és szabályozási környezet változásai}

A szülői döntések és bölcsődéztetési elképzelések szerepének vizsgálatát Magyarországon az intézményes kisgyermeknevelési rendszer néhány éve történt átalakítása és jelenleg is zajló bővítése teszi aktuálissá. Mivel ezen átalakulás ismerete nélkül az adatok nehezen értelmezhetőek, saját kutatási eredményeink ismertetése előtt erre is röviden kitérünk.

Magyarországon évtizedek óta a három év alatti gyermekek intézményes nevelésének fő intézménye a „hagyományos” bölcsőde volt. Ugyanakkor mivel kizárólag a 10000 főnél nagyobb települések voltak kötelesek bölcsődét üzemeltetni (és még ezen települések közül sem mind tette ezt meg) az ellátást tekintve jelentős területi egyenlőtlenségek alakultak ki. A bölcsődék túlnyomó többségét az önkormányzatok üzemeltetették és üzemeltetik, viszont a férőhelyek után járó állami támogatás meglehetősen szűkös volt, emiatt a rendszerváltás után leépült kapacitások, a szülői igények ellenére, nem épültek vissza. Ezenkívül az erősen formalizált szabályok között müködő bölcsődék nem tudták kielégíteni azon szülők igényeit sem, akik kisebb, rugalmasabb keretek között szerették volna gondoztatni kisgyermeküket. Ezen igények kielégítésére teljesen informális vagy részben szabályozott (és részben finanszírozott) ellátási formák jöttek létre (családi napközik). Egyes hátrányos helyzetű településeken részben civil, részben állami kezdeménye- 
zésre és finanszírozásban, kifejezetten a társadalmi hátrányokat kompenzáló bölcsődék, óvódák hiányát pótló célból Biztos Kezdet Gyermekházak jöttek létre, részben szintén a három év alatti korosztályt célozva.

A fenti helyzeten változtatott, hogy 2017. január 1-jétől módosult a gyermekek védelméről és a gyámügyi igazgatásról szóló 1997. évi XXXI. törvény, és ennek keretében újraszabályozták mind az intézményrendszert, mind az önkormányzatok ellátási kötelezettségét.

A ,hagyományos bölcsődék' mellett ekkortól megjelentek a 'mini bölcsődék', és a szolgáltatási elven működő 'munkahelyi bölcsődék', illetve a 'családi bölcsődék' is (utóbbiak jellemzően a korábbi családi napközikből alakultak át). Ettől az átalakítástól függetlenül, valamilyen oknál fogva a bölcsődei rendszeren kívül maradva, de egyre jobban intézményesített formában müködnek a biztos kezdet gyermekházak is.

A szabályozási módosítás másik fontos eleme, hogy ha a bölcsődei ellátásra a településen legalább öt gyermek tekintetében igény jelentkezik, vagy a település 3 év alatti lakosainak a száma meghaladja a 40 fót, akkor az önkormányzat - az eredeti tervek szerint 2018, a jelenlegi szabályozás szerint 2020 végétől - valamilyen módon köteles lesz gondoskodni az érintett gyermekek bölcsődei ellátásáról. A szabályozás változásához komoly bölcsődefejlesztési pályázatok is társultak (jellemzően EU-s forrásokból), illetve jelentősen növekedtek a gondozott gyermekek után járó állami normatív jellegű támogatások is. A dolgozó szülők számára olyan támogatás került bevezetésre (bölcsődei támogatás) amely kifejezetten a bölcsődei térítési díjakat kompenzálja ${ }^{1}$.

Ezen intézkedések együttes hatására jelentős férőhelynövelési programok indultak be, és az ambiciózus kormányzati tervek szerint a bölcsődei férőhelyek száma a 2018-as 47 ezer körüliről² 2022-re 70 ezer főre növekszik majd.

\section{Az bölcsődézetési tervek Magyarországon - leíró eredmények}

A következő, a gyermeket vállalók bölcsődéztetési terveire vonatkozó eredmények, a Kohorsz18 - Magyar születési kohorszvizsgálat várandós mintájából származnak. A 2018-ban zajló kutatás keretében védőnők segítségével 8409, 7. hónapban lévő magzatról, a várandós nőkről és társadalmi-gazdasági körülményeikről gyüjtöttünk részletes adatokat (lásd Veroszta, 2018a, 2018b).

A Kohorsz18 kutatás várandós szakaszában a szülés előtt álló várandósoktól a szülés utáni terveik felől is érdeklődtünk, többek között azt is meg-

\footnotetext{
${ }^{1}$ Az óvodákkal vagy az iskolákkal szemben a bölcsődék jellemzően nem ingyenesek. Míg a hagyományos bölcsődék esetén térítési díj kérhető, de a fenntartók mintegy fele ilyet nem kér, addig a szolgáltatási alapon mủködő családi vagy munkahelyi bölcsődében alapvető, hogy van a szülők által fizetendő térítési díj.

2 2018. május 1-jére vonatkozó KSH-adatok szerint az országban ekkor 40648 hagyományos bölcsődei férőhely, 5840 családi bölcsődei férőhely, 625 mini bölcsődei férőhely, 56 munkahelyi bölcsődei férőhely volt.
} 
kérdeztük, tervezik-e, hogy a megszületendő gyermeket bölcsődébe adják, ha igen, mikor, a gyermek hány éves korában. A bölcsődei típusokat nem választottuk külön, mert az új szabályozás miatt a szülők nagy része még nem ismerte a megváltozott intézményi kereteket.

Így a kérdőívnek a szülés utáni tervekre vonatkozó részében a várandósnak feltett kérdés egyszerűen így hangzott: „A baba mennyi idős korában adná őt bölcsődébe?

- nem tervezi, hogy bölcsődébe adja a gyermeket _____ éves és ___ _ hónapos korában."

'Vonal alatti' (tehát nem előzetesen felkínált) válaszlehetőségként szerepelt a 'tervezi, de nem tudja, mikor', a 'nem tudja, és a 'nem kíván válaszolni'.

A kapott adatok arra utalnak, hogy mai magyar várandósok ${ }^{3}$ jelentősen megosztottak ezen a téren. Mintegy $45 \%$-uk azt tervezi, hogy a gyermeket bölcsődébe adja, 50 \% az ezt nem tervezők aránya, $5 \%$ pedig bizonytalan.

A bölcsődéztetést tervezőkre szűkítve a sokaságot, mintegy 8\%-a nem tudja, hogy a gyermeket milyen idős korban szeretné bölcsibe adni. 9\% azok aránya, akik igen későn, szinte már óvodás korban, (a gyermek 2 és fél éves korában vagy később) tervezik a bölcsődei beíratást. A bölcsődéztetést tervezők erös többsége, 64\%-a gyermek kétéves kora környékén, (19-29 hónapos korban, legjellemzőbben kétéves korban) tervezi bölcsődébe adni a babát. A bölcsit tervezők mintegy nyolcada, $12 \%$-a tervezi 13-18 hónaposan a gyermek beíratását, $6 \%$ egy éves korban, míg szinte alig valaki (1\% körül) a születendő gyermek egy éves kora előtt. Ezek az adatok arra utalnak, hogy a bölcsőde jellemzően egy igen rövid életszakasz intézménye: az érintettek többsége a gyermek kétéves korától az óvodai beíratásig tervezi igénybe venni.

A 2018-as terveket ${ }^{4}$ a 2011-es népszámlálás tényadataival tudjuk összevetni. A népszámlálási adatbázis ugyanis az összes kisgyermek adatait tartalmazza és abból havi bontásban megállapítható, hogy az adott korú gyermekek milyen arányban jártak akkor bölcsődébe. Az eredmények elég egyértelműek: 2018-ban plusz igények a 2011-es tényadatokhoz viszonyítva szinte kizárólag a gyermek 24 hónapos korát követően keletkeztek. Amennyiben tehát nőtt egyáltalán a szülők bölcsődéztetési hajlandósága az elmúlt időszakban, az a kettő és hároméves kor közötti időszakra vonatkozik. (1. ábra)

\footnotetext{
${ }^{3}$ Az elemzés alapegysége a 'magzat' nem pedig a 'várandós', hiszen a kutatás a gyermekeket és nem az anyákat követi majd. Ez praktikusan csak azt jelenti, hogy az ikerterhesek válaszai 'duplán' számítanak az eredmények számításakor. Mivel ez az eredményekben érdemi változást nem jelent, az egyszerűség kedvéért az adatokra, mint a 'várandósok elképzeléseire' hivatkozunk.

${ }^{4}$ A 'nem tudja, mikor' választ adókat arányosan szétosztottuk az életkort megjelölők megoszlása alapján, - 'nem tudja, hogy szeretné-e bölcsődébe íratni' választ adók felét arányosan szétosztottuk, másik felét nem tervezettnek tekintettük, - a 'nem kíván válaszolni' választ adókat nem tervezőknek tekintettük.
} 


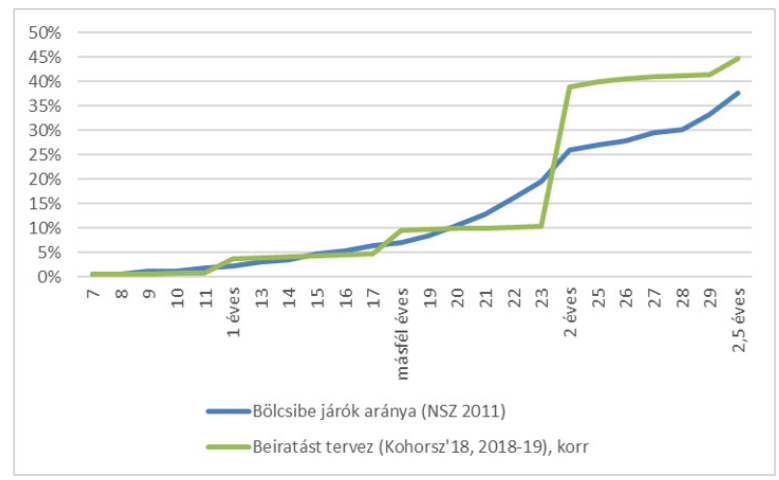

1. ábra

Bölcsődébe járó (2011) és beíratni tervezett gyermekek (2018) aránya a gyermek kora szerint.

(Forrás: Saját számitás a 2001. évi népszámlálás és a Magyar Születési Kohorszvizsgálat adatai alapján)

A vizsgált kérdés szempontjából nagyon fontos, hogy a tervek igen erősen összefüggenek az anya iskolai végzettségével. Az alapfokú végzettségü várandósok $24 \%$-a, a szakmunkás végzettségúek 34\%-a, az érettségizettek 46\%-a, a felsőfokú végzettséggel rendelkezők 58\%-a tervezi, hogy gyermekét bölcsődébe adja. Fontos eredmény az is, hogy az alacsony végzettségü kismamák nem bizonytalanok, hanem elutasítóak a bölcsődét illetően: 71\%-uk egyértelműen nem tervezi születendő gyermeke bölcsődei beíratását. Mivel a válaszadók 7 . hónapban lévő váranadósok, így jellemzően nem lehet azt feltételezni, ekkorra terveikről már külső nyomásra mondtak volna le (például mert sikertelenül próbálták a gyermeket beíratni az intézménybe), sokkal valószínűbb, hogy esetükben valóban elutasító hozzáállásról van szó. 


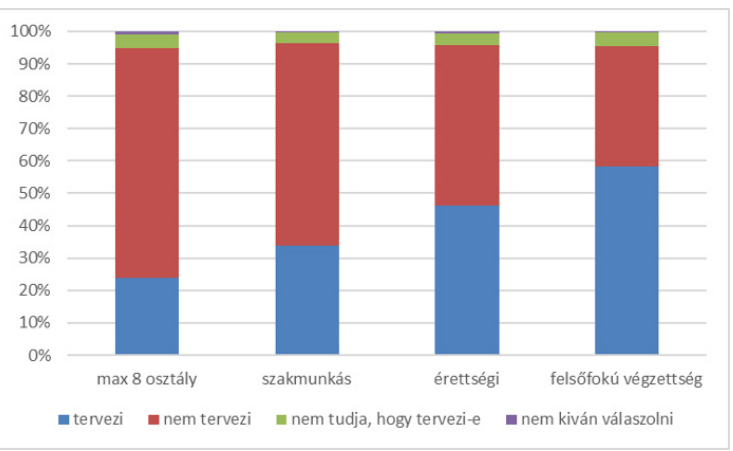

2. ábra

Bölcsödéztetési tervek a várandós iskolai végzettsége szerint.

(Forrás: Magyar Születési Kohorszvizsgálat, várandós szakasz)

Ugyanezt a másik oldalról nézve megállapítható, hogy míg a várandósok között mintegy $30 \%$ a felsőfokú végzettségűek aránya, addig a bölcsődéztetni tervezett gyerekek anyái között ez az arány 40\%. (2. ára)

A bölcsődéztetési tervek talán nem meglepő módon erősen összefüggenek az anya egyéb társadalmi jellemzőivel: a fővárosiak és a központi régióban lakók, az idősebbek, az első vagy még inkább a második gyermeküket vállalók az átlagnál egyértelműen nagyobb arányban tervezik, hogy a születendő gyermeket bölcsődébe adják.

Ezzel szemben például a nagycsaládos, három vagy több gyermekes várandósok alig negyede tervezi, hogy a születendő gyermek bölcsődés lesz. Hasonlóan alacsonyak a bölcsődéztetési szándékok a fiatal (25 év alatti) várandósoknál.

A kutatásban nem csak a tervekről, hanem a vélekedésekről is érdeklődtünk, minden várandóst megkérdeztünk, hogy „Mit gondol, mi a jó a babának, meddig kellene otthon maradnia vele az anyának a munkába való viszszatérés előtt?" 
1. táblázat

Mit gondol, mi a jó a babának, meddig kellene otthon maradnia vele az anyának a munkába való visszatérés elött?

\begin{tabular}{|l|l|c|c|}
\hline \multicolumn{2}{|l|}{} & $\mathbf{N}$ & $\mathbf{\%}$ \\
\hline & legalább a baba féléves koráig & 66 &, 8 \\
\cline { 2 - 4 } & legalább a baba egyéves koráig & 300 & 3,6 \\
\cline { 2 - 4 } & legalább a baba másféléves koráig & 447 & 5,3 \\
\cline { 2 - 4 } & legalább a baba kétéves koráig & 2158 & 25,7 \\
\cline { 2 - 4 } & a baba hároméves koráig & 4898 & 58,2 \\
\hline $\begin{array}{l}\text { a baba hároméves korán túl, akár állandó } \\
\text { jelleggel is }\end{array}$ & 438 & 5,2 \\
\cline { 2 - 4 } & nem tudja & 67 &, 8 \\
\cline { 2 - 4 } & nem kíván válaszolni & 8409 & 100,0 \\
\cline { 2 - 4 } & Total & & 45 \\
\hline
\end{tabular}

Az eredmények egyértelműek és hasonlóak a korábbi országos mintákból (Makay 2018) származó eredményekhez: a várandósok 63\%-a úgy gondolja, hogy az a jó a babának, ha legalább hároméves korig az anya otthon marad vele. Az ebből a szempontból megengedőbbek túlnyomó többsége (az összes válaszadó: 26\%), is csak kétéves korig 'megy le'. A kétéves kor előtti munkavállalást csupán a várandós kismamák mintegy 10\%-a tartotta a baba szempontjából jónak. Az ideák - a tervekhez hasonlóan - szintén igen nagy arányban összefüggtek az anya iskolai végzettségével: az alacsony iskolai végzettségű anyák sokkal nagyobb arányban tartották azt jónak, ha az anya legalább három évig otthon marad a gyermekekkel.

Ezek az ideák összevetve a bölcsődéztetési tervekkel arra is utalnak, hogy ma Magyarországon míg a családok egy része belső indíttatásból tervezi a születendő gyermek bölcsődébe adását, nem tart attól, hogy ez a babának nem jó, addig nem kevesen külső - jellemzően anyagi, munkahelyi - kényszerből, fenntartásaik ellenére tervezik gyermekük bölcsődébe adását. Ennek jele, hogy még azon várandósok negyede (26\%-a) is bölcsődébe készül adni születendő gyermekét, aki egyébként úgy vélekedik, hogy a babának valójában az lenne a jó, ha az anya legalább hároméves koráig otthon maradna vele a munkába való visszatérés előtt. 


\section{Az anyák bölcsődézetési tervei - regressziós modell és kiemelt csoportok}

Természetesen a bölcsődéztetési tervek mögött meghúzódó különféle tényezők nem függetlenek egymástól: az alacsonyabb iskolai végzettségü, sokgyerekes várandósok nagyobb arányban laknak olyan településen, ahol nincs bölcsőde. Így például egy olyan kétváltozós összefüggés, amely azt mutatja, hogy az alacsony iskolai végzettségü családokban kisebb a bölcsődéztetési szándék, előfordulat, hogy csak látszólagos, mert - például - a településszerkezetre vezethető vissza. Annak érdekében, hogy az ilyen látszólagos összefüggéseket kiszűrjük többváltozós matematikai-statisztikai elemzést használtunk, egy többlépcsős logisztikus regressziós modellt építettünk fel. A magyarázni kívánt változó minden esetben az volt, vajon a várandós tervezi-e a gyermeket bölcsődébe íratni, vagy sem. A bizonytalanokat, és a válaszhiányokat ebből a modellből kizártuk (N=8030).

Az első modell a magyarázatba az anya korcsoportját, párkapcsolati helyzetét és iskolai végzettségét vonja be. A második modellben ez kiegészül azzal, hogy vajon van-e a településen 'bölcsőde', illetve, hogy a település melyik fejlettség szerinti nagyrégióban helyezkedik el. A harmadik modellbe bevontunk még egy változót: azt, hogy az anya vajon tervezi-e, hogy még a gyermek hároméves kora előtt munkába áll.

A harmadik modell esetén az ok és az okozat már értelemszerủen összekeveredik, hiszen az első két modell magyarázó változói ugyanúgy hatnak a munkavállalási, mint a bölcsődéztetési tervekre, tehát a szubjektív változó bevonása után az objektív magyarázó változók megtisztított értéke már nem igen értelmezhető. Ráadásul lehetséges, hogy valaki azért nem tervez munkába állást, mert nincs lehetősége gyermekét bölcsődébe beíratni, míg az is lehetséges, hogy valaki azért nem akarja bölcsibe adni a babát, mert nem kíván munkába állni. Ennek ellenére érdekesnek tünik a tervek modellbe illesztése, mert ez teszi lehetővé annak megvizsgálását, hogy a bölcsődéztetési tervek mekkora mértékben a munkavállalási tervek függvényei. (Ez nem feltétlen szükségszerű, valaki tervezheti a munkába való visszatérést bölcsődéztetés nélkül, illetve tervezhető a gyerek bölcsődébe adása munkavállalási terv nélkül is.)

A modell referenciacsoportja egy központi régióban, bölcsődével és családi napközivel is ellátott településen élő 40 év feletti, házas, diplomás nő, aki első gyermekét várja és tervezi, hogy visszatér a munkába a gyermek hároméves kora előtt. Az eltérések ehhez a referenciacsoporthoz mérve értelmezendők. (Azaz, például, ha az illető nem az első, hanem a második gyermekét várná nagyobb vagy kisebb eséllyel tervezné-e a gyermek bölcsődébe íratását). Az eredményeket a 2 . táblázat tartalmazza, amelyben a statisztikailag szignifikáns eltéréseket csillagok jelzik. 
2. táblázat

A bölcsődéztetési terveket magyarázó logisztikus regressziós modellek

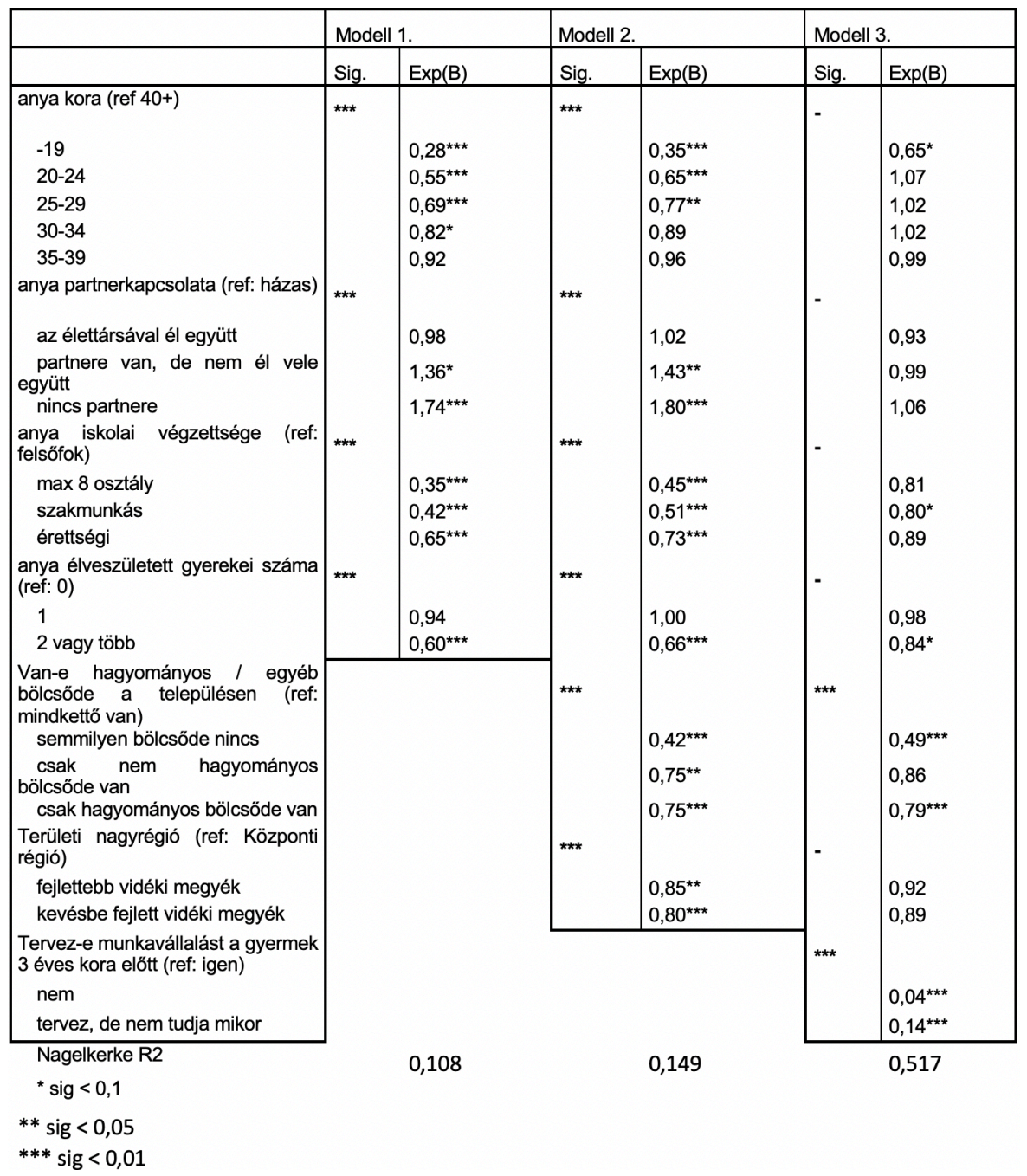

Először az első két modellt érdemes megvizsgálni: az eredményekből látható, hogy az egyre fiatalabb anyák, egyre alacsonyabb arányban tervezik születendő gyermekük bölcsődébe íratását, abban az esetben is, ha figyelembe vesszük a többi objektív változó hatását. Ez mindenképpen meglepő és lényeges eredmény, hiszen az érintett fiatalabb korosztályok jellemzően az újabb, divatosabb társadalmi intézmények, nevelési formák iránt nagyobb nyitottságot mutatnak. Így azt feltételezhettük volna, hogy a fiatal(abb) kis- 
mamák nagyobb arányban számolnak a bölcsődével. Az adatok azonban ezt egyértelmüen cáfolják.

Különösen lényegesek az iskolai végzettség esetén megfigyelhető trendek. A többi változó kontrollálása után is, az alacsonyabb iskolai végzettséggel párhuzamosan csökken a bölcsődei beíratás terve, azzal a fenntartással, hogy a szakmunkás és a csak nyolc osztállyal rendelkező várandósok tervei között már nincs igazán nagy eltérés. Az eredmények tehát azt mutatják, hogy a kisgyermekkori intézményes neveléshez való szelektív hozzáférés nem csak valamiféle diszkrimináció vagy utólagos intézményi szelekció következménye. Az érettségivel nem rendelkező anyák már a gyermek megszületése előtt egyértelműen kisebb arányban tervezik gyermekeik bölcsődébe adását, mint az érettségizett vagy a diplomás nők. Ez a hozzáállás attitűdalapúnak tünik, és azt vetíti előre, hogy a férőhelyfejlesztési programok társadalmi értelemben lefelé kevésbé terjesztik ki majd a bölcsőde igénybevételét. Ha nem következik be változás az érintettek bölcsődéhez való hozzáállásában, akkor az új férőhelyeket elsősorban a diplomás vagy érettségizett anyák gyermekei veszik majd igénybe.

A partnerkapcsolati helyzet esetén más, logikus irányú összefüggés figyelhető meg: az élettársi kapcsolatban és a házasságban élők tervei között nincs érdemi különbség a bölcsődéztetési terveket tekintve. (Ebbe a két csoportba tartozik az anyák túlnyomó többsége). Egyértelmü viszont, hogy azok a várandósok, akik együtt élő partner nélkül vállalták gyermeküket nagyobb eséllyel tervezik igénybe venni a kisgyermekkori ellátásokat. Kisebb mértékben, de igaz ez a látogató partnerkapcsolatban gyermeket vállalókra is. Ez nem meglepő eredmény, hiszen az egyszülős családoknak a gyermekkel kapcsolatos logisztikai-gondozási feladatokban sokkal nagyobb segítségre van szükségük, és itt - a nagyszülő mellett - a bölcsődéknek is komoly szerepe lehet.

A gyerekszámot tekintve szintén érdekesek az eredmények: ez első és a második gyermeket megközelítőleg megegyező eséllyel tervezik bölcsődébe íratni a várandósok. Ezzel szemben a nagycsaládosok sokkal alacsonyabb arányban terveznek a bölcsődével, annak ellenére, hogy ez az intézmény elvileg a sokgyermekes családok számára is segítséget jelenthetne a mindennapi logisztikában.

A második modell már figyelembe veszi annak a településnek a tulajdonságait, ahol a várandós élt. Látható, hogy a központi régióhoz viszonyítva valamivel kisebb a bölcsődéztetési szándék vidéken, mind a fejlettebb, mind a fejletlenebb régióban. Ennél nagyobb a hatása azonban a település intézményi ellátottságának. A referenciacsoportot olyan településen élők jelentik, ahol mind hagyományos, mind más formájú (családi, munkahelyi vagy mini) bölcsőde is rendelkezésre áll. Már az is csökkenti a terveket, ha csak az egyik típusú intézmény érhető el a várandós lakóhelyén. Ha viszont helyben semmilyen intézmény nem érhető el - és nem kevesen, a kutatásban részt vevő válaszadók csaknem 30\%-a ilyen településen él, akkor igen jelentősen visszaesnek már a bölcsődéztetési tervek is. Ez azt mutatja, hogy amennyi- 
ben intézménnyel el nem látott településen nyílik bölcsőde, mini bölcsőde, az nem csak a meglevő igények kiszolgálását biztosítja majd, hanem egyben feltehetően maga is férőhely igényt generál.

A harmadik modell abból a szempontból tanulságos, hogy rámutat arra a tényre, hogy a várandós nők számára ma Magyarországon a bölcsőde elsősorban munkaerőpiaci 'segédeszköz. Látható, mihelyt a harmadik regreszsziós modellben a munkavállalási terveket 'kivontuk' az objektív változókból, a település intézményi ellátottságán kívül szinte semmilyen szignifikáns hatás nem marad. A modellen túllépve az adatbázisból az is megállapítható, hogy akik tervezik gyermeküket bölcsődébe adni, igen nagy eséllyel munkát terveznek vállalni (93\%-ban), illetve akik a gyermek hároméves kora előtt munkavállalást terveznek, azok igen nagy eséllyel (83\%-ban) egyszerre bölcsődéztetésben is gondolkoznak. A települési változó harmadik modellben szignifikánsként megmaradása pedig annak jele, hogy jelenleg Magyarországon a bölcsődékkel nem rendelkező településeken vannak számottevő (mintegy 31\%-os) arányban olyan anyukák, akik úgy terveznek munkavállalást, hogy nem terveznek bölcsődéztetést. További kutatási kérdést jelenthet, hogy ők hogyan szeretnék megoldani gyermekük ellátását mialatt dolgoznak, illetve a későbbiekben sikerül-e megvalósítaniuk terveiket.

Megvizsgáltuk azt a kérdést is, hogy a túlzott bölcsődei férőhelykínálat nem befolyásolja-e az anyákat olyan irányban, hogy abban az esetben is bölcsődéztetést tervezzenek, amennyiben nem terveznek munkavállalást. Túlzott bölcsődei kínálatot azon településeken feltételeztünk, amelyben 2017-ben a bölcsődei férőhelyek több mint egy ötöde betöltetlen maradt. Ilyen településen csak 154 anya élt, így az alacsony esetszám miatt a következtetések óvatosan kezelendők, ugyanakkor arra utalnak, hogy nincs ilyen összefüggés. Azokon a településeken gyakoribb az a jelenség, hogy valaki bölcsődéztetést tervez, de munkavállalást nem, ahol 'újfajta' (családi, mini vagy munkahelyi) bölcsőde múködött a hagyományos bölcsőde helyett vagy mellett.

Lehetséges, hogy ezek a rugalmasabb intézmények nyújtanak majd lehetőséget a munkavállalást nem, de bölcsődéztetést tervező kismamák részére.

\section{A bölcsődei férőhelyigények becslése az adatok alapján}

A Kohorsz18 kutatás mintájának nagysága és reprezentativitása lehetőséget ad annak becslésére, hogy a bölcsődéztetési tervek mekkora férőhelyigényt jelentenek. Fontos látni, hogy a férőhely-igények megbecslésekor az adott igényt súlyozni kell az igénybevétel hosszával. Például az a gyermek, aki egyéves korától három és fél éves koráig jár bölcsődébe 30 bölcsődei 'férőhelyhónapot' vesz igénybe, aki kétéves korától hároméves koráig az csupán 12 hónapot. Mivel Magyarországon a szülők többsége csupán a gyermek kétéves kora környékén igényli a bölcsődét (amelyet azonban a gyermek hároméves kora után is igénybe vesz), így kapacitásigények szempontjából hazánkban félrevezető annak az OECD-merőszámnak a használata, amely a férőhelyek 
számát a 0-3 éves gyermekek számával veti össze. (Például 1000 három éven aluli gyermekre jutó férőhely.)

Becslésünket két módon készítettük el. Az alsó becslés azt a helyzetet modellezi, amely szerint a gyermekek a tervezett időpontban bekerülnek a bölcsődébe és oda járnak hároméves korukig, majd a harmadik életévük betöltését követő hónapban átkerülnek az óvodába.

A becslésnél azon 4\%-nyi gyermeket, akiknél az anyák bizonytalanok voltak abban, be kívánják-e majd egyáltalán íratni bölcsődébe, fele-fele arányban osztottuk szét a bölcsődés és a nem bölcsődés gyermekek között. Azon anyák esetén, akik úgy nyilatkoztak, hogy bár bölcsődébe akarják íratni a gyereket, de nem tudják mikor (4,3\%), azt feltételeztük, hogy hasonló bölcsődéztetési mintát követnek majd, mint azok, akik tudtak életkort mondani. A válaszolni nem kívánó várandósok esetén $(0,5 \%)$ azt feltételeztük, hogy a gyermek majd nem kerül bölcsődébe.

$\mathrm{Az}$ alsó igénybecslés eredménye szerint a gyermekek 53\%-a nem igényel majd bölcsődei férőhelyet, akik igényelnek, ott az igénybevétel becsült hossza 12,5 hónap. Egy gyermekre így szinte pontosan fél évnyi, 6 hónapnyi bölcsődei férőhely igény $(6,005)$ jutna. Ez azt jelentené, hogy 89807 gyermekkel számolva (ennyi gyermek született 2019-ben), egy ekkora születészámú kohorsz esetén majd mintegy 44941 bölcsődei férőhely tudná kielégíteni az igényeket. Így a 2018-as 47 ezer fő körüli kapacitások - nem számolva a földrajzi egyenlőtlenséggel, országos átlagban nézve - minden további fejlesztés nélkül gyakorlatilag kielégítenék a bölcsődei férőhelyekre vonatkozó igényeket.

Természetesen ez csak abban az esetben lenne igaz, ha és amennyiben a gyermekek csak hároméves korukig látogatnák ezeket az intézményeket. A gyakorlatban azonban nem ez a jellemző, hanem inkább az, hogy a gyermekek a harmadik életévüket betöltve az intézményben maradnak az azt követő augusztusig (tehát a szeptemberi születésű gyermekek csaknem négyéves korukig). Ez az utóbbi gyakorlat a nemzeti köznevelésről szóló törvény és gyermekek védelméről és a gyámügyi igazgatásról szóló törvény által is támogatott/megengedett ${ }^{5}$.

Ez a gyakorlat két módon is jelentősen növeli a féröhely igényeket. Egyfelől abszolút mértékben nőnek az igények, hiszen a három év feletti gyermekek lefoglalják a férőhelyek jó részét, így csökkennek újabb generációk által szabadon betölthető férőhelyek. Ha a felépített modellben az igény felmerülését nem hároméves korig, hanem a harmadik életév betöltését követő au-

\footnotetext{
${ }^{5} \mathrm{Nkt}$ : „a gyermek abban az évben, amelynek augusztus 31. napjáig a harmadik életévét betölti, a nevelési év kezdö napjától legalább napi négy órában óvodai foglalkozáson köteles részt venni" Gyvt. végrehajtására vonatkozó a 15/1998. (IV. 30.) NM rendelet: 42/A. \$ (1) Bölcsődei ellátás keretében a gyermek húszhetes korától nevelhető és gondozható ... ha a harmadik életévét január 1-je és augusztus 31-e között tölti be, az adott év augusztus 31-éig, szeptember 1-je és december 31-e között tölti be, a következő év augusztus 31-éig, ha a szülő, törvényes képviselő nyilatkozik arról, hogy a gyermek napközbeni ellátását eddig az időpontig bölcsődei ellátás keretében kívánja megoldani.
} 
gusztus végéig számoljuk, akkor - a férőhelyet igénylők esetén - az igénybevétel becsült átlagos hossza 18 hónap fölé emelkedik, s az összes gyermekre becsült férőhely-igény nyolc és fél hónapra nő (8 583). Ennek megfelelően az így becsült igények betöltéséhez szükséges férőhelyek száma 64234 férőhelyre emelkedik. Tehát a kimeneti szabályozás önmagában már mintegy $50 \%$-kal növeli a férőhelyigényt!

Másfelől - és ez talán még nagyobb gond - amennyiben a bölcsődei belépés időpontja rugalmas, de a kilépési időpont nem életkorhoz, hanem az óvodai nevelési év kezdetéhez igazodik, akkor ebből következik, hogy minél inkább távolodunk a szeptembertől, annál inkább nő a férőhely igények száma. Tehát a férőhelyigények éven felüli felmerülése igen egyenetlenné válik. Ha a magyarországi bölcsődei rendszer mindenkit az igényelt időpontban venne fel, de július végén/augusztusban 'engedne ki' akkor a férőhelyek jelentős részét egész évben betöltetlenül kellene hagyni, ami egyébként egy igen pazarló rendszer is lenne. Ha másik végletként teljesen rugalmatlan kilépéssel készítjük el a becslő modellt, e szerint nem folyamatosan 64 ezer férőhelynyi igény becsülhető, hanem ez az igény a naptári hónapok függvényében ingadozik. Szeptember elsején elég lenne 45 ezer férőhely, de az igény hónapról-hónapra nőne, és augusztus 31-re az igény már 83 ezer férőhely körül lenne, majd a gyermekek óvodába távozásával ez az érték szeptember 1-re ismét lezuhanna. (3. ábra)

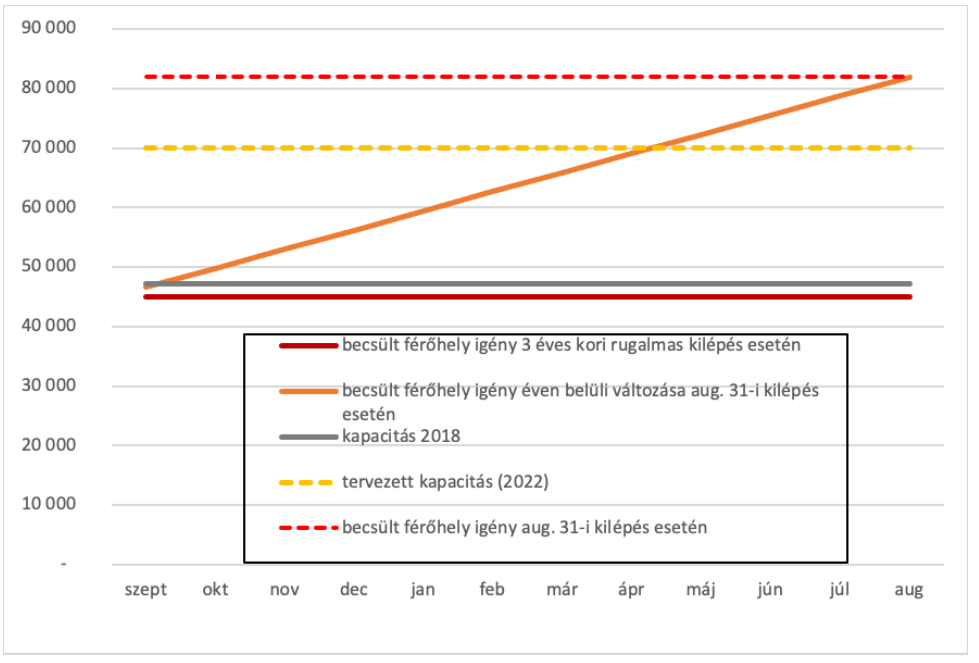

3. ábra

Becsült bölcsődei féröhelyigények különféle forgatókönyvek esetén.

(Forrás: Saját számitás a Magyar Születési Kohorszvizsgálat - várandós szakasz adatbázis alapján) 
Természetesen ez utóbbiak hipotetikus és szélsőséges számok, hiszen nyilván nem életszerü, hogy tömegek nyári szünet idején júliusban vagy augusztusban kezdik a bölcsődét, míg májusban 'csupán' 72 ezer körüli férőhelyigény becsülhető. Ennyiben tehát a célként kitüzött 70000 férőhely reálisnak becsülhető, főként mivel újabb településeken nyitott intézmények újabb igényeket generálnak majd (lásd a logisztikus regressziós modell eredményeit).

\section{Következtetések}

A férőhelyek típusainak és számának növelése egyre több család számára lehetővé teszi, hogy bölcsődéztetési terveit megvalósítsa. Emiatt felértékelődik, és a jövőben még jobban fel fog értékelődni a szülői bölcsődéztetési szándékok, tervek jelentősége.

Eredményeink szerint azonban ezeknek a terveknek és szándékoknak létét erőteljesen meghatározza a családi háttér. Az anyák megosztottak ezen a téren, aki tervezi, jellemzően csak rövid időre, kétéves korban vagy azt követően kívánja bölcsődébe íratni gyermekét. Az alacsony iskolai végzettségű szülők körében azonban igen jelentős fenntartások figyelhetőek meg az intézményes kisgyermekellátással szemben, jellemzően nem is tervezik gyermekük intézménybe történő beíratását, az érettségivel nem rendelkező anyák mintegy négyötöde azt tartja ideálisnak, ha az anya legalább a gyermek hároméves koráig otthon marad a gyermekkel. Amennyiben nem sikerül az alacsony státuszú családokba született gyermekeket valós demográfiai súlyukhoz jobban közelítő mértékben bevonzani az intézményekbe, a bölcsődei férőhelyek növekedése nemhogy a társadalmi különbségeket nem fogja csökkenteni, hanem éppen növelheti ezeket. Külföldi tapasztalatok arra utalnak, hogy ez társadalmilag káros hatásokkal járhat. Ennek elkerülésére az intézményi fejlesztések (bölcsődeépítés, férőhely növelés, fejkvóta rendezés) mellett, cél kellene legyen a bölcsődei rendszer társadalmilag célzott népszerüsítése, vagy valamiféle preferálási rendszer bevezetése.

A Kohorszvizsgálat adatai arra is rámutatnak, hogy mivel a bölcsődéztetést tervező szülők jellemzően továbbra is igen rövid időben (a gyermek kétéves korától az óvodáig) gondolkodnak a bölcsődében, így a férőhelyigények szempontjából a kritikus pont valójában a kimeneti szabályozás kérdése. Amennyiben a bölcsődés gyerekek egy jelentősebb része hároméves kor betöltését követően átkerülne az óvodákba, úgy ez lényegesen kisebb kielégítetlen igényeket és alacsonyabb éven belüli kapacitáskihasználási ingadozást, és így olcsóbb egy főre eső fenntartási költségeket eredményezne a bölcsődei rendszerben. A beiskolázási szabályok 2020-tól tervezett/bekövetkező szigorítása, miszerint jóval nehezebb lesz az 'évvesztessé válás' elég sok gyermeket 'kiszappant' majd az óvodákból, ezzel technikai értelemben lehetővé téve a bölcsődések korábbi 'beóvodáztatását'. Kérdés, hogy ehhez illeszkedően nem lenne-e érdemes finomítani a bölcsődei ellátásba történő be-, illetve az onnét történő kilépés részletszabályozását. 


\section{Irodalom}

Blaskó Zs. (2010). Meddig maradjon otthon az anya? - A gyermekfejlődés szempontjai. Esély, 21(3), 89-116.

Brilli, Y., Del Boca, D., \& Pronzato, C.D. (2016). Does child care availability play a role in maternal employment and children's development? Evidence from Italy. Review of Economics of the Household, 14, 27-51. https://doi.org/10.1007/s11150-013-9227-4

Del Boca, D. (2002). The effect of child care and part time opportunities on participation and fertility decisions in Italy, Journal of Population Economics, 15(3), 549-573. https://doi.org/10.1007/s001480100089

Bauernschuster, S., Hener, T. \& Rainer, H. (2016). Children of a (Policy) Revolution: The Introduction of Universal Child Care and Its Effect on Fertility. Journal of the European Economic Association, 14(4), 975-1005. https://doi.org/10.1111/jeea.12158

Capizzano, J. \& Adams, G. (2004). Children in Low-Income Families Are Less Likely to Be in Center-Based Child Care. The Urban Institute. https://doi.org/10.1037/ e688872011-001

Havnes, T. \& Mogstad, M. (2011). No child left behind: Subsidized child care and children's long-run outcomes. American Economic Journal: Economic Policy, 3(2), 97-129. https://doi.org/10.1257/pol.3.2.97

Keller, J. (2018). Az esélykiegyenlítés egyenlőtlen feltételei: a koragyerekkori szolgáltatások intézményi aszimmetriái. Esély, 29(5), 48-75.

Hódi, Á., \&.Tóth, E. (2016). A különböző szocioökonómiai státuszú tanulók iskolakezdéskor mért elemi alapkészségeinek és a későbbi szövegértés teljesítményének alakulása az óvodában eltöltött évek tükrében. Iskolakultúra, 26(9), 51-72. https://doi.org/10.17543/ISKKULT.2016.9.51

Hank, K. \& Kreyenfeld, M. (2003). A Multilevel Analysis of Child Care and Women's Fertility Decisions in Western Germany. Journal of Marriage and Family, 65(3), 584-596. https://doi.org/10.1111/j.1741-3737.2003.00584.x

Huston, A. C., Chang, Y. E., \& Gennetian, L. (2002). Family and individual predictors of child care use by low-income families in different policy contexts. Early Childhood Research Quarterly, 17(4), 441-469. https://doi.org/10.1016/S08852006(02)00185-0

Liang, X., Fuller, B. and Singer, J. (2000). Ethnic Differences in Child Care Selection: The Influence of Family Structure, Parental Practices, and the Home Language. Early Childhood Research Quarterly, 15(4), 357-384. https://doi.org/10.1016/ S0885-2006(00)00071-5

Lukács, P. (2017) Egy megvalósult és egy tervezett reformról. Educatio, 26(4), 557 566. https://doi.org/10.1556/2063.26.2017.4.4 
Makay, Zs. (2018). Kisgyermekes anyák munkavállalása és az ezzel kapcsolatos vélemények változása Magyarországon. Magyar Tudomány, 179(11), 17021716. https://doi.org/10.1556/2065.179.2018.11.11

Melhuish, E., Sylva, K., Sammons, P., Siraj-Blatchford, I., Taggart, B., Phan, M., ... et al. (2008). Preschool influences on mathematics achievement. Science, 321, 1161-1162. https://doi.org/10.1126/science. 1158808

Nyitrai, Á. (2015). Kisgyermekek nevelése a családban és a bölcsődében. Kaposvári Egyetem Pedagógiai Kar.

Simon, A., Owen, C., \& Hollingworth, K. (2017). "Is Targeting Formal Childcare the Best Way to Meet the Needs of Families in Britain?" American Journal of Educational Research, 5(7), 794-800.

Szabó-Morvai, Á. \& Lovász, A. (2017). Childcare and Maternal Labor Supplya Cross-Country Analysis of Quasi-Experimental Estimates from 7 Countries. BWP, 2017/3. MTA KRTK KTI.

Verity, C.-B. \& Garnham, A. (2010). Childcare: A review of what parents want Equality and Human Rights Commission Research Report Series University of Plymouth.

Webb, M. A. \& Kernaghan, D. (2014). Believe in childcare? The childcare needs of ethnic minority communities in Northern Ireland. Barnardo's Northern Ireland.

Veroszta, Zs. (2018, Ed.). Kohorsz ,18. Magyar Születési Kohorszvizsgálat módszertani leirás. A várandós kutatási szakasz elókészitése. Kutatási Jelentések 99. KSH Népességtudományi Kutatóintézet.

Veroszta, Zs. (2018, Ed.). Kutatási koncepció. Kohorsz '18 Magyar Születési Kohorszvizsgálat. Kutatási Jelentések 100. KSH Népességtudományi Kutatóintézet. https://doi.org/10.21543/Kut.2018.100 


\section{Kapitány, B.}

\section{Plans for nursery in Hungary}

Research questions related to the institutionalized forms of early childhood care (this primarily means various forms of nursery the so called "bölcsőde" in Hungary), are located at the intersection of disciplines. In our study, we are using the data of the Cohort 18 - Hungarian Birth Cohort Study to present the plans and needs of pregnant women in Hungary for nursery in general and according to their social characteristics. We examine how is demographically, socially determined who, what types of families plan / want to send their children to nursery. We analyse the effect of the differences in the plans to the inter-generational reproduction of social inequalities. We calculate the actual capacity needs for nursery, in addition we present how this required capacity can be influenced by regulate the flexibility of the nursery-kindergarten transition.

Keywords: nursery, parental needs, Growing Up in Hungary Study

Kapitány Balázs: https://orcid.org/0000-0002-3560-1119 